\title{
Chapter 12 \\ Facilitator and Peer Support \\ in Collaborative Curriculum Design
}

\author{
Arkato Gendole Anto and Fer Coenders
}

\section{Introduction}

English is the language of instruction in Ethiopian higher education, but most students have inadequate command of English (Kahsay, 2012). Communicative language teaching (CLT) is a widely accepted approach to language teaching (Gray \& Klapper, 2009; Harmer, 2007; Richards, 2006) that can address this problem. CLT emphasizes the development of students' communicative competence, ability to use language for meaningful communication, and ability to produce grammatically correct sentences in a language (Richards, 2006; Richards \& Farrell, 2005).

However, the quality of English language teaching in Ethiopian higher education is challenged due to under-qualified teachers (MoE, 2005). Based on the results of a needs and context analysis (Anto, Coenders, \& Voogt, 2012), a collaborative professional development program (CPDP) (Austin, 2002; Loucks-Horsley, Hewson, Love, \& Stiles, 2010) aimed at promoting communicative language teaching (CLT) by university English language teachers was designed and piloted at an Ethiopian university. The CPDP was intended to help the teachers improve their CLT knowledge and skills in order to improve student learning, engage the teachers in studentcentered learning approaches, and have teachers collaborate with their colleagues and support each other's professional learning. Facilitators, teachers recognized for their professional compentencies, their cooperativeness and their reputation among fellow teachers, played essential roles in the CDPD. Facilitators were subject specialists, instructional specialists, change agents and mentors for their colleagues.

\footnotetext{
A. G. Anto

School of Graduate Studies, Arba Minch University, Arba Minch, Ethiopia

F. Coenders $(\bowtie)$

Faculty of Behavioral, Management and Social Sciences, University of Twente,

Enschede, The Netherlands

e-mail: f.g.m.coenders@utwente.nl
} 
In a context where many teachers lack prior teacher education and have limited teaching experience, as in Ethiopian higher education, it might be difficult to depend totally on facilitators for sustainable support of teacher learning and implementation of innovative instructional approaches such as CLT. Peer support is often reported as an alternative support for sustainable use of innovative teaching approaches (Topping, 1996). The main purpose of this study was to explore whether peers could take over the mentor role from the facilitators during CLT implementation. Hence, in this study, peer support is compared to the mentoring role as enacted through facilitator support, with respect to effects on teaching practice, student learning and teacher learning.

\section{Theoretical Underpinnings}

\section{Communicative Language Teaching (CLT)}

CLT encourages interactive language learning through authentic communication to students in a meaningful way (Gray \& Klapper, 2009; Richards, 2006). CLT is characterized by: (a) involving students actively in the teaching-learning process; (b) using students' authentic experiences and materials as inputs for language learning; (c) providing students with chances for practicing and using new language items in their real communication; (d) facilitating students' collaborative learning; (e) using an integrated-skills approach (combining all skills); (f) communicating language learning purposes to learners; (g) teaching grammar/vocabulary in contextualized texts; (h) integrating assessment with language teaching; (i) tolerating students' language errors; and ( $\mathrm{j}$ ) using the target language for communication in the classroom. As a result, CLT fosters the social relationship between the teacher and learner, makes students have a sense of ownership of their own learning, and thereby enhances their motivation (Richards, 2006; Tsai, 2007; Ur, 2003).

\section{Mentoring and Peer Coaching as Strategies of Professional Development}

Mentoring and peer coaching are teacher professional development strategies that involve two or more teachers working together towards the improvement of their professional knowledge, skills and classroom practices (Guskey, 2000; LoucksHorsley et al., 2010; Richards \& Farrell, 2005). They can bring teachers together who might not normally have a chance to interact and provide opportunities for them to share ideas and expertise and a chance to discuss professional problems and concerns. Teachers can grow professionally as they develop themselves in their profession (Richards \& Farrell, 2005). The difference between mentoring and peer coaching lies in the hierarchical relationship of the participants, as explained below. 
Mentoring refers to a professional learning strategy whereby an experienced teacher provides guidance and feedback to a novice teacher (Richards \& Farrell, 2005). Regular opportunities for discussion about professional goals, sharing of ideas and successful practices, reflection on ongoing practices, on-the-job observations and strategies for improvement are arranged (Guskey, 2000). Mentoring relationships can benefit both the mentor and the mentee (Guskey, 2000; Richards \& Farrell, 2005; Triple Creek Associates, 2007). Mentors are helped by sharing their own expertise with a colleague and expanding it, by improving their leadership skills (Richards \& Farrell, 2005; Triple Creek Associates, 2007), and by gaining new insight into an issue when a mentee explains why he or she does a certain activity (Loucks-Horsley et al., 2010). It also triggers the mentor to reflect on his or her own teaching when observing a mentee's teaching (Richards \& Farrell, 2005). Similarly, when working with mentors, mentees can build on their existing expertise, knowledge and teaching skills as they try new teaching strategies, enact a new curriculum and receive feedback and reflect on their new practices (Loucks-Horsley et al., 2010).

In this study, we use the definition from Richards and Farrell (2005) for peer coaching: a process of reciprocal relation in which colleagues work together to reflect on current practices, expand, refine, and build new skills, share ideas; teach one another; conduct classroom research; or solve problems in their instructional process. Like mentoring, peer coaching is an ongoing process that involves a training stage followed by various other extended activities such as classroom teaching and lesson observation, providing of feedback and critical reflection on class performance by the teacher being coached (Galbraith \& Anstrom, 1995). It provides opportunities for participating teachers to look at teaching problems and to develop possible solutions, and it develops collegiality between colleagues (Richards \& Farrell, 2005). It offers benefits to both the coaching and coached teacher. The coaching teacher gets the satisfaction of helping a colleague, renews his or her own teaching through the coaching process and gets professional recognition from serving as a coach. The coached teacher gains knowledge from a trusted peer, receives constructive, nonthreatening feedback on his or her teaching practices, and thereby expands his or her teaching repertoires. Coached teachers experience significant positive changes in their knowledge and behaviors when they receive appropriate support and specific feedback over an extended time (Joyce \& Showers, 2002). Moreover, peer coaching reduces the sense of isolation that teachers tend to feel (Richards \& Farrell, 2005).

Richards and Farrell (2005) considered lesson observation, feedback provision and reflective discussion as essential components of effective mentoring and peer coaching. A teacher observes a colleague's lesson and notes important points for later reflective feedback and discussion. In conducting the observation, the observer may focus on lesson design, lesson execution and classroom management or other issues (Guskey, 2000). To promote teacher learning and to improve classroom teaching practice, feedback and reflection should be non-judgmental and nonevaluative (Thorn, McLeod, \& Goldsmith, 2007). 


\section{The Collaborative Professional Development Program (CPDP)}

The CPDP had three components: a seminar, an implementation phase and an evaluative workshop (see also Fig. 12.1). During the seminar, the teachers were trained on the essentials of CLT by an expert in English teaching, supported by the facilitators and the researcher. In design teams, supervised by the facilitators, the teachers collaboratively designed and practiced micro-lessons with the help of teacher guides, and collectively discussed and reflected on the design and practice of the micro-lessons. During the implementation phase, the teachers were split into two groups. Three teams consisting of two teachers and one facilitator each (facilitatorsupported teachers; FST); and three teams in which two teachers supported each other (peer-supported teachers; PST) were formed. The teachers taught lessons in the course Communicative English Skills and were observed by a peer or a facilitator. In principle, each teacher was observed three times. For each observation, each teacher had pre- and post-observation meetings with the supporting peer or facilitator about the lesson plan and lesson implementation. During lesson execution, the observing peer or facilitator rated the observed teacher's instructional activities with the help of an observation checklist. After execution, first the observed colleague reflected on his/her teaching performance, after which the observing peer or facilitator offered feedback on the lesson implementation, focusing on (1) CLT practice features done successfully, (2) CLT practice features needing improvement and (3) how these could be improved. After agreeing on these issues, the observed colleague jotted down points needing consideration in the following lesson.

During the evaluative workshop, experiences regarding the CDPD were shared. The facilitators and the peer coaches received $4 \mathrm{~h}$ preparation training for the role they assumed during the implementation phase. The training included a presentation by the researcher on activities and procedures of effective mentoring/peer coaching (lesson observation, providing of feedback, individual and group reflection). As the facilitators also had roles in supporting teachers during the seminar,

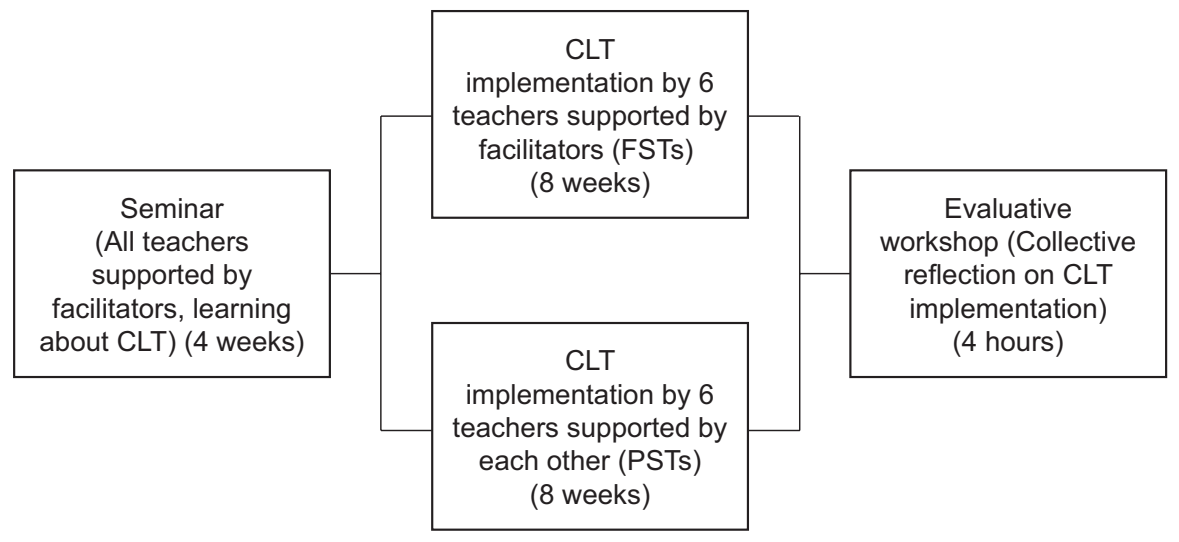

Fig. 12.1 The components and activities of CPPD 
their training included an additional $6 \mathrm{~h}$, which was spent on CLT features, the collaborative design of teacher guides for certain lessons of Communicative English Skills, and discussions and reflections on the teacher guides.

\section{Research Questions}

The focus of this study is on comparing the effects of facilitator support and peer support during the CLT implementation phase (see Fig. 12.1) on the teachers' CLT practice, on their students' learning experiences, and on the teachers' CLT knowledge and beliefs. Teachers' teaching practice, their students' learning, and teachers' self-reported learning are considered as indicators for teacher learning of CLT (Guskey, 2000).

What are the effects of facilitator support and peer support on English language teachers' CLT practice, on their students learning experiences, and on the teachers' own learning?

Specific questions

1. How did the classroom teaching practices of facilitator-supported teachers (FSTs) and peer-supported teachers (PSTs) change after CLT implementation?

2. What changes in student learning were found as a result of the implementation of CLT lessons by FSTs and PSTs?

3. What learning gains (knowledge, skills and beliefs) are reported by FSTs and PSTs and how did CLT implementation contribute to these learning gains?

A case study design (Yin, 2003) using two teacher groups (FSTs and PSTs) as units of analysis was applied to explain teachers' learning in CPDP.

\section{Methods}

\section{Participants}

\section{Facilitators}

Three experienced teachers, Ale, Aba and Gat, acted as facilitators. They had 7, 6 and 5 years teaching experience, respectively, and were between 26 and 29 years old. Each of them had an MA in teaching English as a foreign language (TEFL). They were selected in consultation with the department head for their wellrecognized professional competencies, their cooperativeness, their reputation and acceptance among fellow staff members (cf. Lieberman \& Mace, 2009; Lieberman $\&$ Miller, 2004). 


\section{Teachers}

Twelve novice bachelor's degree holding teachers (10 males; 2 females) who were teaching Communicative English Skills at the time of the program implementation participated in the study. While ten of them had 2 years of teaching experience, the remaining two each had only 1 year of experience. They were between 22 and 25 years old. Six of them had some experience with CLT but the other six did not have any CLT preparation. When assigning the teachers to peer (PST) or facilitator (FST) support, four pairs indicated that they wanted to be supported by peers, and the other two wanted facilitators. One pair was easily willing to change from peer to facilitator support. Therefore, the PST group consisted of three pairs of teachers, and the FST group of three pairs of teachers mentored by a facilitator. Six teachers (one from each pair) were randomly selected to be interviewed and to participate in lesson observation.

\section{Students}

All students of the sections in which the teachers taught Communicative English Skills completed pre-post intervention questionnaires on the teachers' CLT practices. Two student groups were formed to conduct pre-post intervention focus group discussions, composed of students taught by the FSTs and PSTs who participated in interviews and lesson observation. Each group consisted of six students drawn from three classes (two from each) in which each type of teacher group taught the stated course. The selection was done in consultation with the department head regarding the students' ability to provide genuine information about the issues addressed.

\section{Instruments}

A teacher questionnaire solicited information from the teachers on their CLT knowledge, beliefs, and practice before and at the end of the intervention. The teacher interview was conducted before and after the intervention with three FSTs and three PSTs (one from each of six pairs) on issues similar to those addressed by the questionnaire to supplement the data collected via the questionnaire (Miles \& Huberman, 1994). Lesson observation was used to collect data on teachers' teaching practice. The facilitator interview was used to obtain data on the facilitators' perceptions about teachers' learning and changes in CLT practice. The student questionnaire was employed before and after the intervention to solicit information on teachers' CLT practice. Two focus group discussions (before and after the intervention) were held with each student group to obtain data on changes in the teachers' CLT practice and student learning experiences as a result of CLT implementation. 


\section{Data Analysis}

Descriptive statistics (means and standard deviations) and non-parametric tests (Wilcoxon signed ranks test/Mann-Whitney test) were applied to analyze the student questionnaire data. The reliability of the student questionnaire was calculated (Cronbach's $\alpha$ ) for two teaching practice constructs, general CLT practice $(\alpha=0.79$, 12 items) and listening skill practice ( $\alpha=0.82,8$ items). Data collected via interviews, observations and focus group discussion were analyzed qualitatively using data reduction and data display techniques (Miles \& Huberman, 1994). Data obtained through interviews were transcribed, transported into Atlas.ti (Version 6.2) and analyzed to create thematic codes. Nine thematic codes were generated using deductive coding. Sample interview quotations were re-coded by another coder to check inter-coder reliability of the data. The agreement was found to be excellent (Cohen's $\kappa=0.89$ ).

\section{Findings}

\section{Change in Teaching Practice}

To see the effects of the intervention on CLT practice by FSTs and PSTs, a Wilcoxon signed ranks test on the student questionnaire data was conducted for the two teacher groups. The results showed that, according to their students, both teacher groups made significant improvements in their general CLT practice and listening skill practice between pre- and post-intervention (Table 12.1).

A Mann-Whitney test showed that PSTs had significantly higher gains than FSTs with regard to general CLT practice after CLT implementation No significant difference was noticed between the teacher groups for listening skill practice (Table 12.2).

Table 12.1 Effects on FSTs and PSTs CLT practice (according to students)

\begin{tabular}{|c|c|c|c|c|c|c|c|}
\hline $\begin{array}{l}\text { Teacher } \\
\text { groups }\end{array}$ & $\begin{array}{l}\text { Constructs of } \\
\text { teaching } \\
\text { practice }\end{array}$ & $\mathrm{N}$ & \begin{tabular}{|l|} 
Pre \\
intervention
\end{tabular} & \begin{tabular}{|l|}
$\begin{array}{l}\text { Post } \\
\text { intervention }\end{array}$ \\
$\mathrm{M}(\mathrm{SD})$
\end{tabular} & Z & $\begin{array}{l}p \\
\text { (1-tailed) }\end{array}$ & $\begin{array}{l}\text { Effect size } \\
\text { (Cohen's d) }\end{array}$ \\
\hline \multirow[t]{2}{*}{ FSTs } & $\begin{array}{l}\text { General CLT } \\
\text { practice }\end{array}$ & 187 & $3.2(0.48)$ & $3.5(0.45)$ & -7.4 & 0.001 & 0.8 \\
\hline & $\begin{array}{l}\text { Listening skill } \\
\text { practice }\end{array}$ & 188 & $3.1(0.63)$ & $3.5(0.47)$ & -7.3 & 0.001 & 0.8 \\
\hline \multirow[t]{2}{*}{ PSTs } & $\begin{array}{l}\text { General CLT } \\
\text { practice }\end{array}$ & 186 & $3.2(0.54)$ & $3.7(0.46)$ & -8.0 & 0.001 & 1.0 \\
\hline & $\begin{array}{l}\text { Listening skill } \\
\text { practice }\end{array}$ & 182 & $3.1(0.70)$ & $3.7(0.48)$ & -8.4 & 0.001 & 1.0 \\
\hline
\end{tabular}


Table 12.2 Mean gains in CLT practice by FSTs and PSTs (according to students)

\begin{tabular}{|c|c|c|c|c|c|}
\hline & FSTs & PSTs & \multirow[b]{2}{*}{ Z } & \multirow[b]{2}{*}{$\begin{array}{l}\mathrm{p} \\
\text { (2-tailed) }\end{array}$} & \multirow[b]{2}{*}{$\begin{array}{l}\text { Effect size } \\
\text { (Cohen's d) }\end{array}$} \\
\hline & $\begin{array}{l}\mathrm{M}(\mathrm{SD}) \\
(\mathrm{N}=188)\end{array}$ & $\begin{array}{l}\mathrm{M}(\mathrm{SD}) \\
(\mathrm{N}=186)\end{array}$ & & & \\
\hline $\begin{array}{l}\text { General CLT } \\
\text { practice }\end{array}$ & $0.3(0.50)$ & $0.4(0.67)$ & -2.2 & 0.03 & 0.2 \\
\hline $\begin{array}{l}\text { Listening skill } \\
\text { practice }\end{array}$ & $0.4(0.69)$ & $0.5(0.82)$ & -1.2 & 0.2 & 0.1 \\
\hline
\end{tabular}

In the following sections, the changes in practice observed by the students are reported.

\section{FSTs' Changes in Practice}

During the focus group discussion, students of FSTs explained that before the $C P D P$, their teachers showed limited CLT practice in their teaching. All three of the teachers facilitated students' collaborative learning. In addition, two teachers (Abt and Hah) involved students actively in the teaching-learning process and predominantly used English in classroom communication.

After their participation in the CDPD, the three FSTs used authentic materials and experiences in their teaching, provided chances for students to practice and use the new language items inside and outside the classroom, communicated lesson objectives to students at the start of each lesson, and used audio materials for teaching listening skill, as reported by students and, in most cases, validated by facilitators (Table 12.3). Regarding practicing and using the taught language items, one of Abt's students reported, "Now, our teacher usually makes students practice what they learned for real communication. For example, after teaching reported speech, he let one student say something and another student report it to the class." Dam and Hah tolerated students' language errors and used formative assessment techniques to check the progress of student learning. Concerning formative assessment techniques, one of Hah's students stated, "The teacher assessed most of our language learning by continuous classroom observation of our communicative activities and provision of simple quizzes. Consequently, she reduced the weight of the semester-end exam to assess student learning."

Facilitators' interviews confirmed that the teachers changed their CLT practice. But the facilitators also expressed that there were issues that needed further improvement. For instance, one of them said, "I observed improvements in the teachers' practices, possibly caused by their new learning gains in CLT features but still they need to further improve certain issues like involving students actively in their lessons, integrating assessment with language teaching, etc." 
Table 12.3 Teachers' changes in CLT practice

\begin{tabular}{|c|c|c|c|c|c|c|}
\hline \multirow{4}{*}{$\begin{array}{l}\text { CLT features and related } \\
\text { issues }\end{array}$} & \multicolumn{6}{|c|}{ Teachers (pseudonyms) } \\
\hline & \multicolumn{3}{|l|}{ FSTs } & \multicolumn{3}{|l|}{ PSTs } \\
\hline & Abt & Dam & Hah & Dab & Tat & Mag \\
\hline & \multicolumn{6}{|c|}{ Reported after intervention by } \\
\hline \multirow{2}{*}{$\begin{array}{l}\text { Use of students' authentic } \\
\text { materials and experiences }\end{array}$} & Students & \multirow[t]{2}{*}{ Facilitator } & \multirow[t]{2}{*}{ Students } & \multirow[t]{2}{*}{ Students } & Students & Students \\
\hline & Facilitator & & & & Peer & Peer \\
\hline \multirow{2}{*}{$\begin{array}{l}\text { Provision of chances for } \\
\text { students to practice and use } \\
\text { language items }\end{array}$} & Students & \multirow[t]{2}{*}{ Students } & Students & & & \\
\hline & Facilitator & & Facilitator & & & \\
\hline \multirow{2}{*}{$\begin{array}{l}\text { Communication of lesson } \\
\text { objectives }\end{array}$} & Students & Students & Students & & Students & Students \\
\hline & Facilitator & Facilitator & Facilitator & & Peer & Peer \\
\hline \multirow{2}{*}{$\begin{array}{l}\text { Contextualization of grammar } \\
\text { and vocabulary teaching }\end{array}$} & & & & & \multirow[t]{2}{*}{ Students } & Students \\
\hline & & & & & & Peer \\
\hline \multirow{2}{*}{$\begin{array}{l}\text { Integration of assessment } \\
\text { with language teaching }\end{array}$} & & \multirow[t]{2}{*}{ Students } & Students & & Students & Students \\
\hline & & & Facilitator & & Peer & Peer \\
\hline \multirow{2}{*}{$\begin{array}{l}\text { Treatment of students' } \\
\text { language errors }\end{array}$} & & Students & \multirow[t]{2}{*}{ Students } & Students & Students & Students \\
\hline & & Facilitator & & Peer & Peer & Peer \\
\hline \multirow{2}{*}{$\begin{array}{l}\text { Use of audio text to teach } \\
\text { listening }\end{array}$} & Students & Students & Students & Students & Students & Students \\
\hline & Facilitator & Facilitator & Facilitator & Peer & Peer & Peer \\
\hline
\end{tabular}

\section{PSTs' Changes in Practice}

Students from classes taught by PSTs reported that before the CDPD their teachers demonstrated very few CLT features in their teaching. They facilitated students' collaborative language learning, provided opportunities for practice and use of new language items in their daily communication. Students of two teachers (Tat and Mag) added that their teachers actively involved students in the teaching-learning process and predominantly used English in classroom communication.

However, after the CPDP, as seen in Table 12.3, the students of the three PSTs indicated that their teachers used students' authentic materials and experiences in their teaching, tolerated students' language learning errors and used audio material to teach listening lessons. For instance, a student from Mag's class expressed, "In teaching listening, the teacher now uses audio text that we listen to from a laptop. He never used this before. Every student found it interesting." This was also confirmed by their peers. Moreover, students of Tat and Mag disclosed that, after the intervention, their teachers began to communicate lesson objectives, taught grammar and vocabulary in context, and applied formative assessment techniques to assess their students' language learning. One of Tat's students said, "As a new experience, he now communicates lesson objectives at the start of each lesson."

During interview conversations, Tat and Mag showed their agreement with most of the changes in practice reported by their respective students. Tat, who was said to 
use limited CLT features before the intervention, revealed his change in practice after the intervention, "I started to tolerate student mistakes and more encouraged the students for their every effort of language learning (I was a fault finder), communicated lesson objectives at the start of each lesson, used audio text to teaching listening skill lessons etc." However, after the CPDP, although Dab reported applying students' authentic experiences in his teaching, teaching grammar and vocabulary items in context and using audio texts to teach listening skill, his use of authentic materials and teaching of grammar and vocabulary items in context were not verified by his students and his peer. Moreover, he appeared to have low interest in the CPDP as he missed many workshop sessions during the seminar.

\section{Student Learning Gains}

Student learning is considered to be the ultimate goal of teacher professional development (Guskey, 2000). For this reason, we also asked students to report on their learning and asked teachers how they perceived student learning. Student learning in this study refers to their increased motivation to learn English and their increased participation in the teaching-learning process, not to improved language skills, because achieving this needs a longer period of time. In the next sections we report the changes reported by students of FSTs and PSTs about their motivation for and participation in learning English.

\section{Students Taught by FSTs}

Students of FSTs explained that before the CPDP their participation in the teaching learning process was quite limited and their motivation to learn English was low. After the intervention, as they reported and teachers confirmed most of these reports, the students were more motivated to learn the language and increased their involvement in the teaching-learning process. All participating students revealed that their interest in learning the language increased, they spent more time doing different communicative activities, they engaged more intensively in group work, they started learning through listening to audio materials and liked it a lot, they became more confident about contributing to group/pair work and speaking in front of others, and they established a smoother rapport with their teachers. They added that they appreciated this more engaging and interactive approach to language teaching used by their teachers. Concerning student motivation to learn English, a student from Dam's class said, "After observing the keen interest of students to learn English, our teacher said, 'I will teach this your next course again'." Hah's student also noticed changes in the students' learning experience, "After our last discussion, student involvement in the teaching learning process increased. Most of the time, students worked in groups and group members took various roles such as ambassador, secretary, leader, time keeper in carrying out various communicative activities." Dam's 
students added that, after the intervention, they felt more responsible for their own learning. Abt's students also commented that they were encouraged to ask and answer questions, became more delighted with their learning and appreciated their teacher's new teaching approach. One of his students stated, "As our teacher moves around and prompts everybody to contribute to group/pair work, most students are now happy to actively engage in diverse learning tasks and to ask and answer questions. Most of them appreciate his new approach of teaching."

FSTs verified most of the student learning changes reported by their students. For instance, Abt said, "I observed many changes in student learning. They (students) increased their interest to learn English, minimized their stage fright, became more confident to participate in group work, more engaged in the teaching-learning process and more encouraged to ask/answer questions."

\section{Students Taught by PSTs}

Students in the classes taught by PSTs also disclosed that they improved their interest and involvement in language learning activities as the result of the change in their teachers' CLT practice after the teachers' participation in the CPDP. The students appreciated the new engaging and interactive learning tasks. After the CDPD, all students in this group clarified that they increased their contribution to the lessons supported by students' real-life experiences and learned listening skills using audio texts. They added that their teachers treated language learning errors in encouraging ways. Students of Tat and Mag also reported being encouraged to actively participate in various learning tasks, having lesson objectives communicated at the start of each lesson, being taught grammar and vocabulary in context, and being assessed by formative assessment techniques (e.g., quizzes, assignments, observations, class work). The students appreciated these new learning activities and their teachers' efforts to facilitate such communicative tasks. One of Tat's students expressed his appreciation of his teacher's new practices as follows, "Frankly speaking, I like the interactive activities such as debate and role play that our teacher uses in his lessons. I also appreciate his efforts to encourage everybody to participate in the activities." Nevertheless, Dab's students doubted if there was any improvement in their involvement in the teaching-learning process after the intervention. Moreover, they revealed that objectives were not communicated, that grammar and vocabulary were not learned in context, and that they were not assessed by formative assessment techniques. One of his students said, "I feel that there are changes in his teaching, but I am not sure whether he increased student involvement in the lessons after our last discussion. He usually misses classes and always rushes to cover the course contents."

Most positive student learning experiences were verified by their respective teachers. For instance, Mag articulated a change in his students' learning experience as follows, "My students were quite interested and actively participated in my listening lesson supported by audio texts. I found such texts more motivating for students than teacher-read texts." Despite the validation of students' positive learning experiences, 
the teachers also expressed some concerns with using CLT properly in their teaching, for instance, limited participation by some students in the communicative tasks. Regarding the issue of limited participation of students, Tat stated, "There are still students who remain passive in the classroom most probably because of their low language ability."

\section{Teacher Learning Gains}

\section{FSTs' CLT Learning Gains}

All FSTs reported learning gains from CLT implementation. All of the teachers indicated that CLT implementation enriched the knowledge and beliefs acquired during the seminar or during their pre-teaching education. During CLT implementation, the teachers indicated learning about communication of lesson objectives to students, integration of all skills in teaching the English language and about the importance of using audio text to teach listening. They also became more familiar with the three main stages of teaching reading and listening skills and specific activities undertaken at each stage. The teachers attributed their learning to various experiences during the implementation: facilitator feedback, new student behaviors, use of the teacher guide, their own teaching practice, and self and collaborative reflection on the facilitator's feedback. Dam, for instance, explained his CLT learning gain attributed to his facilitator's feedback as follows: "During one of my writing lessons, I forgot to communicate objectives. After the lesson, my facilitator commented to me about the importance of communicating them. The comment taught me a good lesson and encouraged me to communicate them during the subsequent lessons." Ascribing his learning gain to his facilitator's feedback and subsequent reflection, Abt described it as follows: "My facilitator's feedback on a reading passage lesson, followed by collaborative reflection on the feedback strengthened my knowledge of the stages of a reading lesson. I realized using realistic experiences during the pre-reading stage is quite vital to grab students' attention." Table 12.4 gives details about individual learning gains and attributions.

In addition, from their facilitator's feedback and the teachers' personal reflection on the feedback, the teachers indicated having learned about the use of authentic materials and experiences in making student learning meaningful (Abt and Dam), about providing chances for students to practice and use language items (Abt and Hah) and about treatment of student language errors during a communicative lesson (Dam and Hah). Hah reported her learning as follows: "After observing one of my listening lessons, my facilitator commented that I should avoid overcorrection of students' errors to encourage them to communicate freely. After reflecting on the feedback, I learned well how to treat students' language learning errors."

As a result of the students' increased motivation to learn English in a communicative way, the teachers expressed their interest in continuing to learn about CLT to 
Table 12.4 FSTs' learning gains and source of learning (from interview \& questionnaire)

\begin{tabular}{|c|c|c|c|}
\hline \multirow{2}{*}{$\begin{array}{l}\text { Learned CLT features and } \\
\text { related issues }\end{array}$} & \multicolumn{3}{|c|}{ Teachers (pseudonyms) } \\
\hline & Abt & Dam & Hah \\
\hline $\begin{array}{l}\text { Enrichment of CLT } \\
\text { knowledge/belief }\end{array}$ & $\begin{array}{l}\text { Facilitator } \\
\text { feedback, reflection, } \\
\text { hand-out reading }\end{array}$ & $\begin{array}{l}\text { Facilitator feedback, } \\
\text { reflection, hand-out } \\
\text { reading }\end{array}$ & Facilitator feedback \\
\hline $\begin{array}{l}\text { Use of authentic materials } \\
\text { and experiences }\end{array}$ & $\begin{array}{l}\text { Facilitator feedback } \\
+ \text { self-reflection }\end{array}$ & Facilitator feedback & \\
\hline $\begin{array}{l}\text { Provision of chances for } \\
\text { students to practice and use } \\
\text { language items }\end{array}$ & $\begin{array}{l}\text { Facilitator } \\
\text { feedback, reflection }\end{array}$ & & $\begin{array}{l}\text { Facilitator feedback, } \\
\text { reflection }\end{array}$ \\
\hline $\begin{array}{l}\text { Communication of lesson } \\
\text { objectives }\end{array}$ & Facilitator feedback & $\begin{array}{l}\text { Facilitator feedback, } \\
\text { teacher guide }\end{array}$ & $\begin{array}{l}\text { Facilitator feedback, } \\
\text { teacher guide }\end{array}$ \\
\hline $\begin{array}{l}\text { Contextualization of } \\
\text { grammar and vocabulary } \\
\text { teaching }\end{array}$ & Own practice & & \\
\hline $\begin{array}{l}\text { Integration of assessment } \\
\text { with language teaching }\end{array}$ & & & $\begin{array}{l}\text { Facilitator feedback }+ \\
\text { reflection }\end{array}$ \\
\hline $\begin{array}{l}\text { Integration of language } \\
\text { skills }\end{array}$ & Own practice & $\begin{array}{l}\text { Facilitator feedback, } \\
\text { own practice }\end{array}$ & $\begin{array}{l}\text { Facilitator feedback, } \\
\text { reflection }\end{array}$ \\
\hline $\begin{array}{l}\text { Treatment of students' } \\
\text { language errors }\end{array}$ & & $\begin{array}{l}\text { Facilitator feedback, } \\
\text { self-reflection }\end{array}$ & $\begin{array}{l}\text { Facilitator feedback, } \\
\text { self-reflection }\end{array}$ \\
\hline $\begin{array}{l}\text { Use of audio text to teach } \\
\text { listening }\end{array}$ & $\begin{array}{l}\text { Facilitator } \\
\text { feedback, } \\
\text { collaborative } \\
\text { reflection }\end{array}$ & $\begin{array}{l}\text { Facilitator feedback, } \\
\text { collaborative } \\
\text { reflection }\end{array}$ & $\begin{array}{l}\text { Facilitator feedback, } \\
\text { collaborative } \\
\text { reflection }\end{array}$ \\
\hline $\begin{array}{l}\text { Stages of teaching listening/ } \\
\text { reading skill }\end{array}$ & $\begin{array}{l}\text { Facilitator } \\
\text { feedback, } \\
\text { self-reflection }\end{array}$ & $\begin{array}{l}\text { Facilitator feedback, } \\
\text { own practice }\end{array}$ & $\begin{array}{l}\text { Facilitator feedback, } \\
\text { own practice, } \\
\text { collaborative } \\
\text { reflection }\end{array}$ \\
\hline
\end{tabular}

improve how they practiced it. They said that as a result of noticing new learning behaviors by the students, they increased their confidence and satisfaction with teaching English and enhanced their self-efficacy. AbT explained his learning from changes in students' learning behaviors as follows, 'After noticing students' new learning behaviors, I improved my interaction with students, increased my confidence and satisfaction with teaching and boosted my interest to collaborate with my colleagues. I also want to continue learning about CLT and improving its practice."

\section{PSTs' CLT Learning Gains}

As seen in Table 12.5, PSTs reported that they achieved useful learning gains from various components of CLT implementation, particularly from their collaborative sharing, use of the teacher guide, their own teaching practice, students' new 
Table 12.5 PSTs' learning gains and source of learning (From interview \& questionnaire)

\begin{tabular}{|c|c|c|c|}
\hline \multirow{2}{*}{$\begin{array}{l}\text { CLT features and related } \\
\text { aspects }\end{array}$} & \multicolumn{3}{|l|}{ Teachers (pseudonyms) } \\
\hline & Dab & Tat & Mag \\
\hline $\begin{array}{l}\text { Enrichment of CLT } \\
\text { knowledge/belief }\end{array}$ & $\begin{array}{l}\text { Collaborative sharing } \\
\text { with peer, peer } \\
\text { feedback, personal } \\
\text { reflection }\end{array}$ & $\begin{array}{l}\text { Collaborative sharing } \\
\text { with peer, peer } \\
\text { feedback, students new } \\
\text { reactions }\end{array}$ & $\begin{array}{l}\text { Peer feedback }+ \\
\text { own practice }\end{array}$ \\
\hline $\begin{array}{l}\text { Use of authentic materials } \\
\text { and experiences }\end{array}$ & Own practice & & Own practice \\
\hline $\begin{array}{l}\text { Provision of chances for } \\
\text { students to practice and } \\
\text { use language items }\end{array}$ & & & $\begin{array}{l}\text { Students' } \\
\text { behavior }\end{array}$ \\
\hline $\begin{array}{l}\text { Communication of lesson } \\
\text { objectives }\end{array}$ & Teacher guide & Own practice & \\
\hline $\begin{array}{l}\text { Contextualization of } \\
\text { grammar and vocabulary } \\
\text { teaching }\end{array}$ & $\begin{array}{l}\text { Peer feedback, own } \\
\text { practice }\end{array}$ & & \\
\hline $\begin{array}{l}\text { Integration of assessment } \\
\text { with language teaching }\end{array}$ & & $\begin{array}{l}\text { Own practice, teacher } \\
\text { guide }\end{array}$ & \\
\hline $\begin{array}{l}\text { Treatment of students' } \\
\text { language errors }\end{array}$ & Peer feedback & & Peer feedback \\
\hline $\begin{array}{l}\text { Use of audio text to teach } \\
\text { listening }\end{array}$ & $\begin{array}{l}\text { Peer feedback, teacher } \\
\text { guide }\end{array}$ & $\begin{array}{l}\text { Peer feedback, student } \\
\text { reactions, teacher guide }\end{array}$ & $\begin{array}{l}\text { Peer feedback, } \\
\text { teacher guide }\end{array}$ \\
\hline $\begin{array}{l}\text { Stages of teaching } \\
\text { listening/reading skill }\end{array}$ & $\begin{array}{l}\text { Peer feedback, } \\
\text { collaborative reflection }\end{array}$ & $\begin{array}{l}\text { Peer feedback, } \\
\text { collaborative reflection }\end{array}$ & $\begin{array}{l}\text { Peer feedback, } \\
\text { collaborative } \\
\text { reflection }\end{array}$ \\
\hline
\end{tabular}

reactions, and from peers' feedback followed by individual or collaborative reflection on the feedback. All of them clarified that they were able to enrich their knowledge of CLT from collaborative sharing with their peers (Dab and Tat), peer feedback on their lesson enactment (all), personal reflection on the feedback (Dab), students' new behaviors (Tat), and from his own teaching practice (Mag). Tat explained his learning from new student reactions as follows: "The active involvement of the majority of students in their lessons inspired me to know more about CLT and practice it in better ways in my teaching. It also improved my confidence for teaching English and promoted my self-esteem." Moreover, attributing their learning to the teacher guide and their own teaching practice, respectively, Dab and Tat reported achieving useful changes in knowledge and belief concerning the significance of communicating lesson objectives at the start of a lesson.

Furthermore, all of the PSTs reported that as the result of their being exposed to various elements of CLT implementation, they recognized the advantages of using audio texts to teach listening skill and became more familiar with the three main stages of teaching listening/reading skills in a communicative way and the activities accomplished at each stage of teaching these skills. All of the teachers attributed their learning gains regarding the use of audio texts to peer feedback and use of the 
teacher guide that assisted their teaching. Tat said that his students' new reactions also contributed to his learning about the issue. Again, all of them responded that their learning about the stages of teaching listening and reading skills emerged from peer feedback and personal reflections on that feedback. Mag explained his learning gain about the stages from various sources as follows: "After teaching reading comprehension, receiving useful feedback from my peer and collaboratively reflecting on the feedback, I enriched my understanding of the three stages (pre, while and post reading) of teaching reading skills."

Still more, PSTs expressed that after noticing encouraging changes in student learning behaviors, the teachers were motivated to continue learning about CLT and improve their practice of it. "The active involvement of the majority of students in their lessons inspired me to learn more about CLT and practice it in my teaching in better ways. It also improved my confidence for teaching English, promoted my selfesteem" said Tat.

\section{Conclusions and Discussions}

This study investigated the effects of facilitator and peer support on English language CLT teaching practice, student motivation and participation, and teacher learning. Teachers' teaching practice, their students' learning, and teachers' selfreported learning were considered to be indicators for teacher learning of CLT (Guskey, 2000).

This study showed that, according to students, the CLT practice of FSTs and PSTs improved after CLT implementation. Both teacher groups applied students' authentic materials and experiences in their teaching, and used audio materials to teach listening lessons. FSTs also provided chances for students to practice and use the new language items in the classroom, and communicated lesson objectives to students at the start of each lesson. PSTs, on their part, tolerated students' language learning errors. PSTs gained significantly more from the intervention than FSTs as far as general CLT practice. The difference between FSTs and PSTs might be explained by the reduced psychological stress and the collaborative working environment PSTs experienced during their classroom observation, provision of feedback and reflection. Supporting this view, Joyce and Showers (2002) argued that peer coaching when provided with appropriate support and specific feedback on instructional practices enables the coached teachers to experience significant positive changes in their knowledge and practices. It allows the coached teachers to gain knowledge from trusted peers, receive constructive and nonthreatening feedback on their teaching practices and thereby expand their teaching repertoires, and reduces their sense of isolation (cf. Richards \& Farrell, 2005; Thorn et al., 2007). The professional status gap between the facilitators and FSTs might have restricted the FSTs from optimally benefiting from the professional support of the facilitators. 
This study also showed that after the intervention, students of both teacher groups increased their motivation to learn English and their involvement in the teachinglearning process, and appreciated and carried out more communicative tasks facilitated by their teachers than before the intervention. These student learning experiences again increased the teachers' interest in and confidence for teaching English, enhanced their self-esteem and inspired them to continue to learn about CLT and to further improve their practice of it. This might further favorably affect the teachers' CLT knowledge and beliefs, as Guskey (2000) and Loucks-Horsley et al. (2010) have indicated that improved student learning outcomes have powerful effects not only on aspects of student learning, but also on teachers' knowledge, beliefs, attitudes and classroom experiences.

From teachers' self-reported data on their learning, a significant positive influence of the intervention on PSTs' beliefs was found, but not on the beliefs of FSTs. This result agrees with the student report that PSTs had more gains in CLT practice than FSTs did. However, FSTs reported a gain in their knowledge and skills about CLT practice. A reason for the latter finding might be PSTs' overestimation of their CLT practice before intervention, as their large mean values on the pre-test suggest. Teacher interviews revealed that the teachers in both groups experienced important learning gains from CLT implementation: enrichment of their knowledge and beliefs about CLT and its features; identification of the advantages of using audio texts to teach listening skills, and familiarity with the three main stages of teaching listening/reading skills in a communicative way. The groups mainly attributed their learning gains to facilitators'/peers' feedback and individual or collaborative reflections on the feedback, their collaborative sharing, use of the teacher guide and their own teaching practice. Studies by Fiszer (2004) and Harmer (2007) pointed out that feedback on and reflective discussion of teaching performance, where teachers challenge each other's' ideas, clarify their views and expose their beliefs for deep and critical analysis are important sources of teacher learning. The qualitative findings for FSTs and PSTs regarding their CLT learning tended to be more comparable than the quantitative outcomes suggested.

In this study, we consider the results regarding changes in teacher classroom practice as a more reliable indicator for teacher learning than teachers' self-reported changes in student and teacher learning, because teacher practice data were provided by external sources. Accordingly, after CLT implementation, although both teacher groups reported benefiting from the intervention, students showed that PSTs have larger gains in general CLT practice than FSTs. In spite of the promising gains in CLT practice by FSTs and PSTs, three areas need specific attention. First, most teachers were found to be challenged to actively involve students in their lessons. The challenge could be attributed to the students' inadequate English ability, the way they were taught English at lower levels, and the cultural traditions of Ethiopia (Lakachew, 2003). The English language proficiency students develop at the lower 
grades is insufficient for practicing English communication in their classes. Grammar teaching and learning are emphasized. Moreover, Ethiopian cultural traditions and values do not encourage (especially youngsters) speaking in front of others. This might discourage the students from expressing their ideas in front of their classmates. Second, the majority of the teachers were found not to contextualize grammar and vocabulary instruction in their teaching practice. The challenge could arise from the complex nature of this CLT feature, which therefore needs extended time to learn and properly use it in communicative lessons (Richards, 2006). Third, limited interest in participating in the professional development intervention and in practicing its ideas, on the part of some teachers, could be another factor restricting the teachers from setting up and using more communicative tasks that inspire their students to actively engage in the tasks. Al-Mekhlafi and Ramani (2011), Cherkowski (2012), and Guskey (2000) asserted that teacher attitudes play a vital role in determining teacher learning of innovative instructional approaches and implementation of them in classroom teaching practices.

Although students' quantitative data showed that PSTs had larger gains in CLT practice than FSTs, data obtained from peers and facilitators could not provide clear evidence to substantiate the difference. The disagreement between student data and peer/facilitator data might be due to the limited number of classroom observations conducted by facilitators or peers. Facilitators and peers could not possibly obtain adequate information to validate all student data about the teachers' CLT practice. Contrary to the reported practice difference between the teacher groups, empirical studies (Guskey, 2000; Hord, 2004; Loucks-Horsley et al., 2010; Richards \& Farrell, 2005) have shown that both forms of support play vital roles in improving classroom practice of innovative instructional approaches such as CLT. The strategies bring teachers together to interact and share their ideas and expertise, and to discuss professional problems and concerns (Richards \& Farrell, 2005).

This study has implications for Ethiopian higher education, where the culture of action-based in-service professional development is almost non-existent. It demonstrates that professional development arrangements in which teachers collaborate with their peers or facilitators to enact innovative teaching approaches (such as CLT), to receive and provide feedback on their enactment and to reflect on the feedback has promise for Ethiopian higher education. In arranging such professional development, peer support appears to be more effective, sustainable, cheaper, and promotes a culture of collaboration among teachers (Fullan, 2007). The study further suggests that a professional development initiative for enhancing understanding and class use of CLT should pay due attention to teacher attitude and contextual factors, including cultural traditions of the country. Finally, for the intervention to function properly as far as continuing to enhancing English language teachers' CLT learning and implementation, further studies should address the feasibility of sustainably integrating peer support in such collaborative in-service professional development arrangements in Ethiopian higher education context. 


\section{References}

Al-Mekhlafi, A., \& Ramani, P. N. (2011). Expectation versus reality: Communicative approach to EFL teaching. Studies in Learning, Evaluation, Innovation and Development, 8(1), 98-113.

Anto, A. G., Coenders, F., \& Voogt, J. (2012). Assessing the current implementation of communicative language teaching for English language teachers in Ethiopian universities. Staff and Educational Development International, 16(1), 51-69.

Austin, A. E. (2002). Academic staff in times of transformation: Role, challenges and professional development needs. In D. W. Chapman \& A. E. Austin (Eds.), Higher education in the developing world: Changing contexts and institutional response (pp. 233-250). London: Greenwood Press.

Cherkowski, S. (2012). Teacher commitment in sustainable learning communities: A new 'ancient' story of educational leadership. Canadian Journal of Education, 35(1), 56-68.

Fiszer, E. P. (2004). How teachers learn best: An ongoing professional development model. Lanham, MD: Scarecrow Education.

Fullan, M. G. (2007). The new meaning of educational change (4th ed.). New York: Teachers College Press.

Galbraith, P., \& Anstrom, K. (1995). Peer coaching: An effective staff development model for educators of linguistically and culturally diverse students. Directions in Language Education, 1(3). Retrieved October 31, 2012, from http://www.ncela.gwu.edu/pubs/directions/03.htm

Gray, C., \& Klapper, J. (2009). Key aspects of teaching and learning in languages. In H. Fry, S. Ketteridge, \& S. Marshal (Eds.), A handbook for teaching and learning in higher education: Enhancing academic practice (3rd ed., pp. 110-165). New York: Routledge.

Guskey, T. R. (2000). Evaluating professional development. Thousand Oaks, CA: Corwin Press.

Harmer, J. (2007). The practice of English language teaching (4th ed.). Essex, UK: Pearson Education Limited.

Hord, S. M. (2004). Professional learning communities: An overview. In S. M. Hord (Ed.), Learning together, leading together: Changing schools through professional learning communities (pp. 5-14). New York: Teachers College, Columbia University.

Joyce, B. R., \& Showers, B. (2002). Student achievement through staff development (3rd ed.). Alexandria, VA: ASCD.

Kahsay, M. N. (2012). Quality and quality assurance in Ethiopian higher education: Critical issues and practical implications. Doctoral Dissertation. Enschede, The Netherlands: University of Twente.

Lakachew, M. (2003). Teachers' attitudes towards communicative language teaching and practical problems in its implementation (MA thesis). Addis Ababa, Ethiopia: Addis Ababa University.

Lieberman, A., \& Mace, D. H. P. (2009). The role of 'accomplished teachers' in professional learning communities: Uncovering practice and enabling leadership. Teachers and Teaching: Theory and Practice, 15(4), 459-470.

Lieberman, A., \& Miller, L. (2004). Teacher leadership. San Francisco: Jossey-Bass.

Loucks-Horsley, S., Hewson, P. W., Love, N., \& Stiles, K. E. (2010). Designing professional development for teachers of science and mathematics. Thousand Oaks, CA: Corwin Press.

Miles, M. B., \& Huberman, A. M. (1994). An expanded source book: Qualitative data analysis (2nd ed.). London: Sage Publications.

MoE. (2005). Improving English language in Ethiopia: Guidelines for English language enhancement in our teacher education institutions. Addis Ababa, Ethiopia: English Language Improvement Program (ELIP).

Richards, J. C. (2006). Communicative language teaching today. Cambridge, UK: Cambridge University Press.

Richards, J. C., \& Farrell, T. S. (2005). Professional development for language teachers: Strategies for teacher learning. New York: Cambridge University Press. 
Thorn, A., McLeod, M., \& Goldsmith, M. (2007). Peer coaching overview. Retrieved October 31, 2012, from http://www.marshallgoldsmithlibrary.com/docs/articles/Peer-Coaching-Overview. pdf

Topping, K. J. (1996). The effectiveness of peer tutoring in further and higher education: A typology and a review of the literature. Higher Education, 32, 321-345.

Triple Creek Associates. (2007). Benefits of mentoring. Retrieved October 31, 2012, from http:// www.3creek.com/booklets/BenefitsBooklet.pdf

Tsai, T. H. (2007). Taiwanese educators' perspective on the implementation of the new English education policy. Doctoral dissertation. Alhambra, CA: Alliant International University.

Ur, P. (2003). A course in language teaching: Practice and theory. Cambridge, MA: Cambridge Publishing Press.

Yin, R. K. (2003). Case study research: Design and methods (3rd ed.). Thousand Oaks, CA: Sage Publications.

Open Access This chapter is licensed under the terms of the Creative Commons Attribution 4.0 International License (http://creativecommons.org/licenses/by/4.0/), which permits use, sharing, adaptation, distribution and reproduction in any medium or format, as long as you give appropriate credit to the original author(s) and the source, provide a link to the Creative Commons licence and indicate if changes were made.

The images or other third party material in this chapter are included in the chapter's Creative Commons licence, unless indicated otherwise in a credit line to the material. If material is not included in the chapter's Creative Commons licence and your intended use is not permitted by statutory regulation or exceeds the permitted use, you will need to obtain permission directly from the copyright holder. 